\title{
CG 画像の感性評価による対話型進化計算を用いたファサードガラス特性 の探索法の研究

\author{
A STUDY OF A SEARCH METHOD OF FACADE GLASS ATTRIBUTES \\ BY AN AESTHETIC EVALUATION OF CG IMAGES APPLYING \\ AN INTERACTIVE EVOLUTIONARY COMPUTATION
}

\author{
松下大輔*, 宗本順三** \\ Daisuke MATSUSHITA and Junzo MUNEMOTO
}

\begin{abstract}
We tried the method to search the glass attributes, which are color, reflectance and transmittance, of objective glass facade images by an aesthetic evaluation of ray-tracing CG applying an interactive genetic algorithm. To verify the method, we firstly used the existent CG image as an objective image and searched it. Resultant acquired image closely resembled the objective image and both glass attributes are also close for the most part. We applied the method to a hotel facade, and reached an image that satisfied an chooser's expectation highly. The availability of this method to search the glass attributes by combining human aesthetic evaluation, high reproducibility of $\mathrm{CG}$ and multiple search procedure of GA was shown.
\end{abstract}

Keywords: Interactive Evolutionary Computation, Aesthetic Evaluation, Search Method, Facade Glass, Computer Graphics, Ray Tracing Algorithm

対話型進化計算, 感性評価, 探索方法, ファサードガラス, コンピュータ・グラフイックス, レイ・トレーシング法

1. はじめに

近年、ファサードにガラスが使用された建物が数多く建設されて いる。ガラスのファサードを持つ建物の外観の印象は、選定するガ ラスの特性によって大きく左右される。また、昼夜で異なる周囲の 光環境も外観の印象に関係する等、ファサードガラスの見え方は多 様である。ガラスの選定においては、部分的なサンプルや他の既存 事例を元に、䇋工後の状態を予測して検討したり、実物のガラスの モックアップで確認をしたりするなど、デザイナーの経験や完成イ メージの推測能力に大きく依存している現状がある。そこで、デザ イナーやクライアント等のガラスの選定を行う者（以下「選定者」） が、望ましい印象をもたらすガラスの特性を効率的に探索する方法 があれば建築設計に有効であると考えられる。

一方、コンピュータ・グラフィックス (computer graphics、以下 $\mathrm{CG})$ の進歩は著しく、コンピュータの演算能力の増大と共に、仮想 現奏感(virtual reality、VR)等の技術が急速に発達しつつあり、今 後もさらなる発展が予想されている。建築設計過程においても、3 次元 C ADによる CG 用いたスタディは、現時点では未熟な面も あるが、対象空間の可視化、把握等に最も有用な手法の一つである。 C G は建築設計過程のあらゆる部分に導入され、不可欠な道具と なっているといえる。人は擬似的に現害空間を表現したCGをもと に、自らの空間認識を補完的に用いて実物を推測し、両者を対応づ けることによりシミュレーションを行う。本論においても、ガラス の性能值である、可視光反射率、透過率等を反映したシミュレー
ションが可能な、レイ・トレーシング法注1) によるC G 画像を扱う ことにより、ガラスの探索を模擬的に行うものとする。

「選定者」の目標とするガラスファサードの印象が明確な場合、目 標の印象をもたらすガラス学同定するには、色や透過率、反射率と いった複数の指標からなるガラスの性能值を知る必要がある。目標 の印象を、手続き的に性能值に翻訳することは、優れた「選定者」で なければ容易ではない。ガラスファサードの印象は、それらの複数 の性能値の複合により決定されるためである。例えば、透過率が大 きいガラスでも、反射率が大で昼間の場合は、周囲の景色の映り込 みによって、透き通って見えなくなったり、一方夜間で建物外部が 暗く、内部が明るい場合は、透過率が大であれば反射率に関わらず 透き通って見えるようになったりすることがあるように、それらの 性能值は互いに依存しあって外観の印象を遒いていると考えられる。

直ちに目標のガラスの性能值を見つけることは簡単でないが、任 意に生成され、現前するガラスファサードの画像に対し、それらが 目標とする印象とどれほど近似しているか、乘離しているか、自ら の感性に基づいて評価することは比較的容易である。なぜ優劣をつ けられるのかを理論的に説明することは困難であるが、対象が具体 的に存在する場合に、それらに対して微妙な相違まで総合的に考慮 して、どれほど好きか嫌いかと直感で判断する能力においては人間 は優れているといえる。このような人間の持つ感性のはたらきを適 切に用いて、代替案を探索して行く方法があれば有効であると考え
* 京都大学大学院工学研究科 助手. 工博

** 京都大学大学院工学研究科 教授・工博
Research Assoc., Graduate School of Engineering, Kyoto University, M. Eng. Prof., Graduate School of Engineering, Kyoto University, Dr. Eng. 
られる。一方、人間は存在する代替案を感性で評価することは可能 であるが、可能な代替案の総数が多い場合、その全てを検討するこ とは、過大な時間や労力を要する。しかしデザインのスタディでは、 一定の時間内に成果を残す必要があることを考慮すると、効率的な 探索が求められる。すなわち、問題空間を適切に絞り込みつつ、か つ広範な問題空間を対象としながら代替案の探索を行う過程が必要 となる。

そこで、目標の印象をもたらすガラスの性能值を効率的に挆索し てゆく手法として、コンピュータが進化計算により、あるガラスの 性能值に基づいたレンダリング画像の代替案の生成を行い、「選定 者」が生成された代替案に評価値を与え、その評価值が次の代替案 の生成に反映されるという、対話型進化計算の可能性が考えられる。 すなわち、「選定者」が目標として持つガラスファサードの印象と、 提示される代替案とを照合し、感性に基づいてそれらの類似度を測 ることで、評価を行う人間と適応システムとの対話により短時間で 効率的に目標に近づいて行くことが期待される（図 1)。

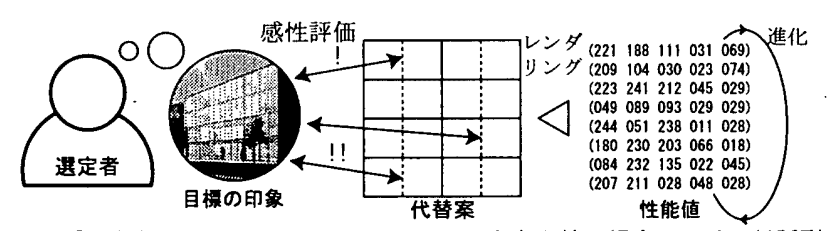

図 1 「選定者」が明確なガラスファサードの印象を持つ場合における対話型 進化計算を用いたガラスの性能值の探索

進化計算は、生物の進化の仕組みを適応システムと捉え、それにア ナロジーを得て効率的に優れた解の探索を行う計算方法であるが、 そこでは同時に存在する複数の解によって探索が進められる。つま り対話型進化計算において各世代で提示される複数の代替案を評価 することは、あるデザインの過程における限定された問題空間を俯 瞰し、次なる新たな問題空間を定義する指針を与えることに相当す る。遺伝子表現されたガラスの性能值を表す代替案に、適者生存や 有性生殖の概念に基づく遺伝的オペレータを適用することにより、 代替案の評価の高い部分構造を進化させてゆく対話型進化計算の手 法は、目標により近い印象をもたらすファサードガラスの性能值の 効率的な探索に有効である（図 2)。

$\langle\mathrm{k}+1$ 時点 $>$

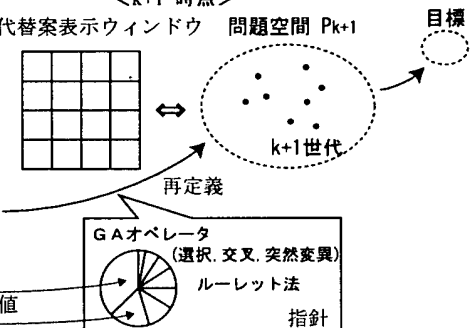

图 2 デザインプロセスと対話型進化計算を援用した代替案の探索との関倸

\section{2. 研究の目的}

本論では、CG画像の感性評価による対話型進化計算を用いる方 法を提示し、その方法が目標のガラスファサードの印象をもたらす ガラスの特性の探索において、有効にはたらくことをシミュレー ションにより確かめることを目的とする。対話型遺伝的アルゴリズ ム (Interactive Genetic Algorithm, 以下 I GA)により、目標の
印象をもたらすガラスの性能值の概要を短時間で効率的に探索して 行くモデルを作成して試行を行い、その有効性を考察する。本論の 方法は、目標のガラスファサードを現実空間の光環境で得るための ガラス選択の精緻なスタディに資する点に意義がある。

\section{3. 対話型進化計算を用いた探索の手順}

はじめに、「ガラスファサードモデル」を作成する。「ガラスファ サードモデル」は、CADアプリケーション内注2）における、対象 とするガラスファサードを持つ建物の 3 次元モデルと、ガラスの性 能值を表す各パラメータからなる。これらの 3 次元モデルやパラ メータを様々に設定して、各々の性能值に対応したレンダリング画 像を作ることができる。この「ガラスファサードモデル」のパラメー 夕を遺伝子化することにより、遺伝的アルゴリズム（以下 G A） と 組み合わせて「選定者」の評価を対話的に取り込んだI G A 用い、 目標のガラスの性能值の獲得を行う。

\section{4. 既往の研究}

C Gは、現実に近似した表現ができることから、建築分野におい ても空間の把握を行うッールとして、これを用いたシミュレーショ ン等が様々に行われ、数多くの研究がなされている (文献 $1 \sim 4$ 等)。 人間の感性をデザインやものづくりに結びつけてゆく研究は、感 性工学の形をとって、多くの工学分野やデザイン分野で様々に成果 を上げている。中でも、進化計算に人間の評価を取り込み、対話的 に人間の要求を明確にしてゆく手法として、対話型進化計算は幾つ かの分野で試みられている。青木、高木 ${ }^{5)}$ は、人間の感性や嗜好を システムに取り込む手法としてインタラクティブEC（対話型進化 計算）を提案し、ライティングデザイン支援における対話型GAの 有効性を明らかにした。建築分野においても、瀧澤、河村、谷 ${ }^{6)}$ は、 対話型進化計算を用いたテーブルデザイン支援において、ユーザー の試行を定量化し、その予測の精度を明らかにした。筆者ら ${ }^{7)}$ は、平 面図形の形態創発を行い、木構造で表される形態構成規則を獲得す るモデルを試みた。また他にも、李、位寄、両角 ${ }^{8)}$ 、宗本、加藤、今 村 $^{9)}$ 、Nguyen、Goldberg、huang ${ }^{10)}$ によって、対話型のモデルが試み られている。

以上関連する既往の研究は様々にあるが、C Gの高度な現実空間 の再現性と、人間の感性評価の能力と、多点探索を行う進化計算に よる適応システムの利点を活用することにより、建築分野の当該デ ザイン問題において有効な方法を提示するものは筆者らのグループ の他には見られない。本論の特色は、目標のファサードガラスの印 象をもたらすガラスの探索という、人間の微妙な感覚が求められる デザイン問題に対して、写実的な空間表現が可能なレイ・トレーシ ング法によるC G 画像の感性評価により、人間と適応システムとの 対話において、より良い代替案を効率的に探索して行く点にある。

\section{5. ガラスファサードモデル}

はじめに、通りに面した南面に幅 $20 \mathrm{~m}$ 、高さ $18 \mathrm{~m}$ のガラスファサー ドを持つ低層の商業建物を想定する。ガラスは単板ガラスで、厚さ は $6 \mathrm{~mm}$ とする。ガラスの性能值は、色（RGB方式）反射率、透過 率とする（図 3)。ガラスのような透明物体の見え方に関係する属性 を設定するパラメータには、透過率、反射率、屈折率があるが、ガ 
ラスファサードモデルのスケールとガラスの厚さの関係から、屈折 の効果は小さいと考えられるので屈折率の值は1.56の定数を用いる。
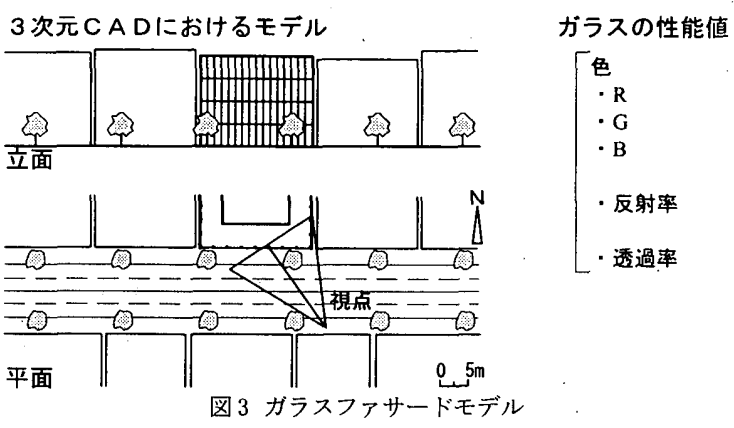

以下に各性能値のC A Dアプリケーションにおける概要を記す。 (1)ガラスの色（拡散反射光）…物体表面が光源からの光を拡散反射 する時、ある色の光を吸収する場合に、その物体表面は着色して見 える。この色をシミュレートする属性を、「色」と呼ぶ。

(2)ガラスの反射（鏡面反射光）…物体表面が色を鏡面反射寸る時、こ れをシミュレートする属性を、「反射」と呼ぶ。

(3)ガラスの透過Nガラスのような透明物体を光が透過するとき、一 部の光は物体表面で反射し、他の光は屈折し、場合によっては、あ る色の光は吸収され、残りの光は反対側の物体表面に到達すると、 ふたたび屈折して射出されていく。これをシミュレートする属性を、 「透過」と呼ぶ。

\section{6. 感性評価による対話型進化計算}

（1）遺伝子コーディングと評価の方法

GA では、二值表現の数值列による遺伝子型と、ある解釈機構に よって遺伝子型を翻訳した実際の問題空間における解である表現型 が用いられる。表現型の評価によって決められる評価値が、遺伝子 型の遺伝的操作に反映されることによって、解の探索が行われる。 本研究では、ガラスの性能值は (1)ガラスの色 (2)反射率(3)透過率から なる。色はRGB 方式により 0 以上 255 以下の 3 つの整数の組で表さ れ、染色体上ではそれぞれ 8 ビットずつとなる。反射率と透過率は それぞれ 0.00 以上 1.00 以下の 100 段階の小数で表され、染色体上

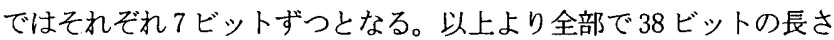
の染色体にコーディングされる(図 4)。ガラス面以外の物体の属性、 無限遠光源、点光源、スポットライト等の光環境、背景は適宜設定 し、固定とする。

画面 (図 5) ${ }^{\text {注 } 3)}$ 左側の代替案表示ウィンドウには、レイ・トレーシ ング法によってレンダリングされた 8 個体の画像を順番に、昼景と 夜景を並べて表示する。「選定者」は表示された 8 個の代替案の感性 評価により、画面右側のスコア入カウィンドウに評価值を入力する。 評価方法は 1 〜の整数で表される 7 段階評価とし、「選定者」の評 価の高い代替案ほど大きい評価値を与えるとする。

\begin{tabular}{|c|c|c|c|c|c|}
\hline \multirow{2}{*}{$\begin{array}{l}\text { ガラスの性能値 } \\
(10 \text { 進数表記 })\end{array}$} & $\bar{R}$ & 惫 & $B$ & \multicolumn{2}{|c|}{ 十反射率 十透過率一 } \\
\hline & 173 & 252 & 222 & 0.10 & 0.90 \\
\hline G Aにおける遺伝子 & 8ビット & 8ビット & $\begin{array}{l}7 \mathbf{\nabla} \\
38 \text { ビット } \\
8 \text { ビット }\end{array}$ & 7ビット & 7ピット \\
\hline & 10101101 & 11111100 & 11011110 & 0001010 & 0101101 \\
\hline
\end{tabular}

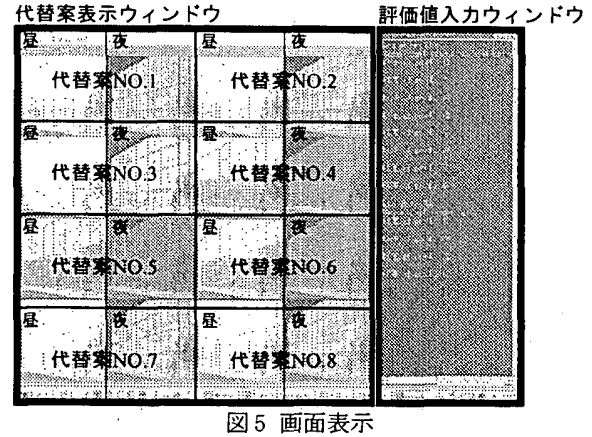

I GAのフローは以下のようになる（図6）。

1）試行の対象とするガラスの色の系統を設定する。

2） I G Aプログラムがランダムに初期個体を 8 個体生成する。

3）色の系統の条件を満たしているかを調心、満たしていない個体は 笑然変異させる。条件に当てはまる個体が全数得られるまで3)を繰 り返す。

4） 10 進数表記に書き換えた 8 組のガラスの性能值を、3 次元 C A D アプリケーションに送り、昼景・夜景それぞれについてレイ・トレー シング法を用いたレンダリング計算を行う。

5）得られた画像を「代替案表示ウィンドウ」に表示する。

6）画面に表示された代替案に対して、「選定者」が評価を行い、評 価值を「スコア入カウィンドウ」に入力する。ここで十分望ましい 代替案が得られたときは、試行を終了する。

7）入力されたスコアをもとに、GA演算（選択、交叉、突然変異） を行い、次世代の個体を生成する。

8）重複する個体を調心、重複する個体は突然変異させ、異なる 8 個 体が得られるまで絽り返す。

9）3）に戻る。

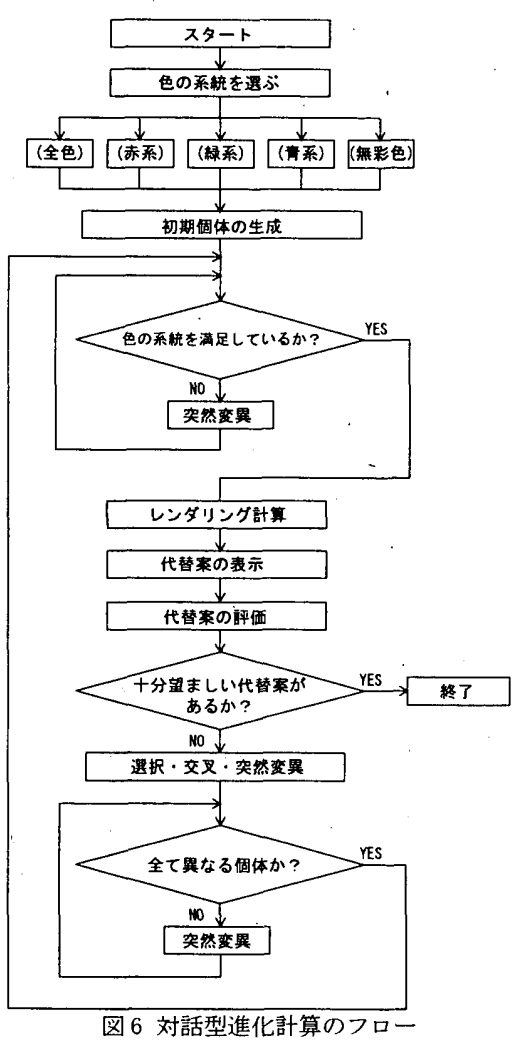


（2）対話型進化計算の試行

1) C G 画像のガラスの探索と性能值の比較検証

「選定者」注4) が図 7 に示す C G 画像の印象を目標として明確に 持っているものと想定した。この予め作成された画像と十分近似し た代替案が得られるまで試行を続ける。得られた画像と、目標の画 像のガラスの性能值を比較することにより、探索が有効に行われて いるか検証する。「選定者」は試行において、C G画像と代替案との 類似度を感性評価し、評価值を与えるのみで、ガラスの性能值を意 識することはないが、参考のため世代ごとに性能值と、与えられた 評価值の推移を拔粋して示す（図 8,9）。

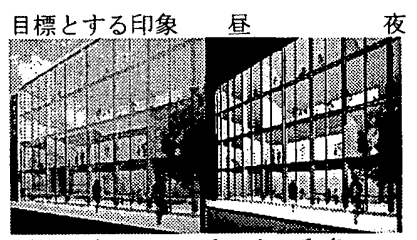

図 7 目標のガラスファサードの印象の C G 画像

第 10 世代において、「選定者」は目標の印象と十分近似した代替 案を得たとみなし、試行を終了した。ランダムに生成された初期世 代の代替案はいずれも目標とする印象との相違が大きかった。初期 世代内で評価が最も高かった代替案の性能值を見ると、目標の印象 をもたらす性能值とは大きく異なることがわかる。すなわちこの試 行は、初期世代において目標に近似した代替案が偶然生成されるこ
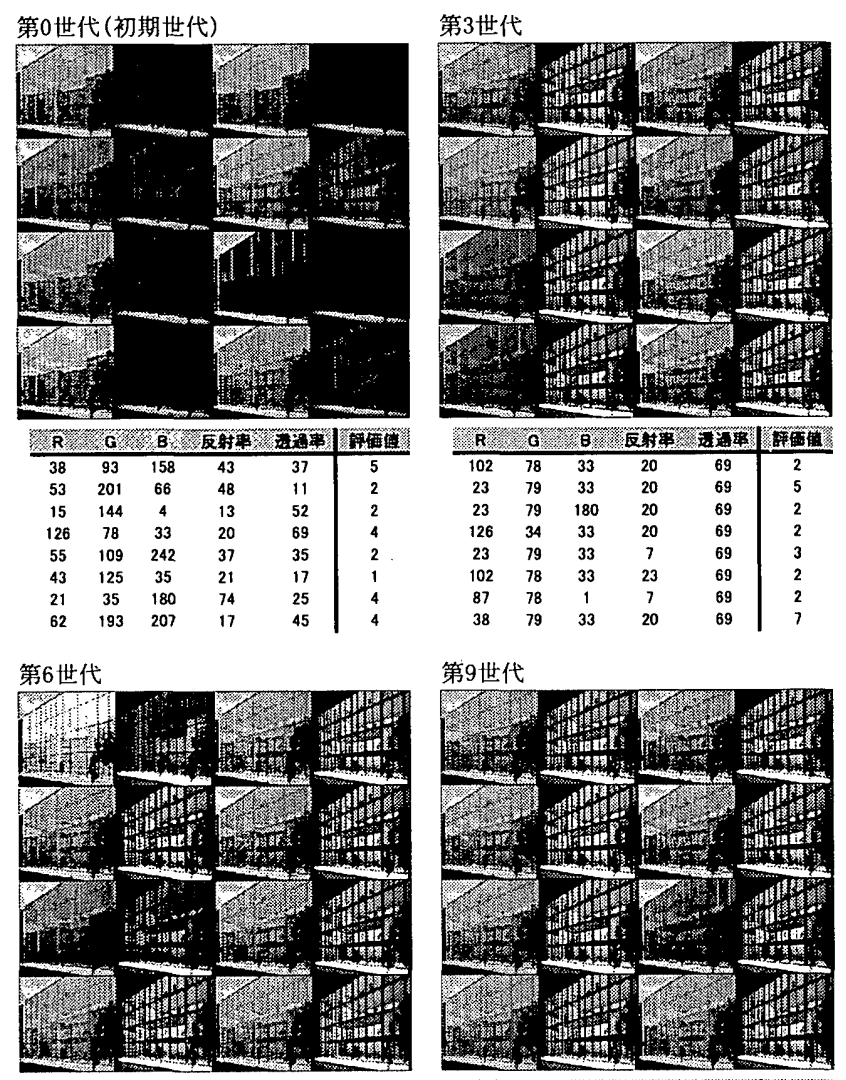

\begin{tabular}{|c|c|c|c|c|c|}
\hline $\mathrm{R}$ & 6 & B & $区 W$ & 道年 & 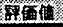 \\
\hline 168 & 247 & 127 & 63 & 26 & 1 \\
\hline 38 & 79 & 161 & 20 & 69 & 2 \\
\hline 6 & 75 & 33 & 21 & 69 & 6 \\
\hline 6 & 79 & 33 & 20 & 69 & 1 \\
\hline 23 & 79 & 33 & 20 & 56 & 2 \\
\hline 6 & 75 & 33 & 20 & 69 & 4 \\
\hline 38 & 79 & 33 & 20 & 69 & 2 \\
\hline 23 & 79 & 33 & 20 & 69 & 2 \\
\hline
\end{tabular}

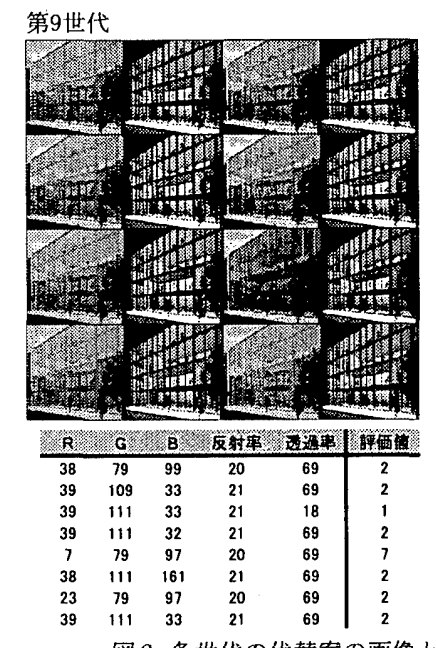

図 8 各世代の代替案の画像と性能值とそれらに与えられた評価值 あると考えられる。

となく開始された。「選定者」が一世代の評価に要する時間は約 15 秒 ほどで、感性に基づいた評価は比較的容易で、即座に行うことがで きた。初期世代から第 5 世代にかけて、代替案は目標の印象に速や かに近づいて行く過程が見られた。それと同時に、突然変異して現 れる代替案以外は、ある一定の範囲内で類似した印象をもたらす代 替案が頻出するようになった。このことは、感性評価と、それを反 映した遺伝的オペレータが、各世代の代替案に適用されることに よって、ファサードガラスの画像を表す遺伝子の中に、「選定者」の 評価の高い部分構造が生まれ、進化して行く過程を表していると予 想される。また一方、第 6 世代以降では、前述の一定の類似性の範 囲を超える、優秀な代替案の出現はしばらく見られなくなった。代 替案の目標への接近は停滞したようにも見られたが、各代替案の微 妙な印象の違い、周囲の風景のガラスへの映り込みや、色合い、ガ ラスを通して見える建物内部の透け具合等の違いを相対的に評価値 に反映させて試行を続けた。この間、初期世代から第 5 世代辺りま での進化のす寸み具合とは違い、このように細部がわずかに異なる 代替案が多く現れた。このようなレンダリング画像に表現される微 妙な印象の差異を「選定者」は、見分けて、どれがより目標に近い か評価した。第 9 世代において、目標の印象にかなり近似している とみなせる代替案が現れ、第 10 世代において「選定者」は、試行 を終了した。改めて目標の画像と、試行で獲得された画像を並べて 比較すると、モニター上での差異はごくわずかであった。目標の画 像を生成したときに用いたガラスの性能値と、獲得された代替案の ガラスの性能值は、図 7 に示される。以上より目標の印象をもたら す少なくとも一つのガラスの性能值の組が獲得され、それは目標の 性能值の組と概ね近似していた。より目標に近い代替案を得るには、 より大きな解像度の画像を用い、さらに長く試行を継続する必要が

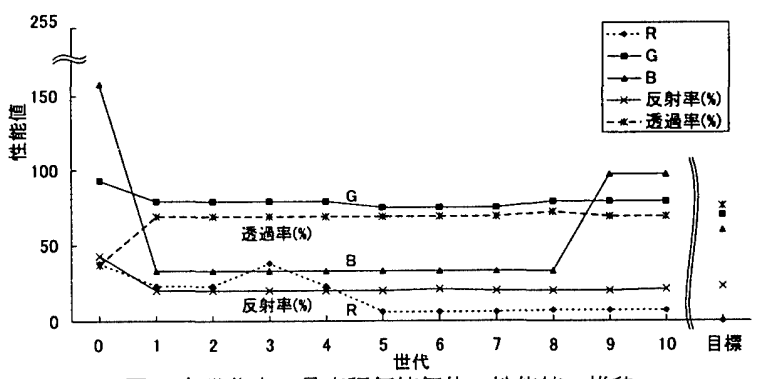

図 9 各世代内の最高評価值個体の性能值の推移

第10世代（試行を扯めた世代）

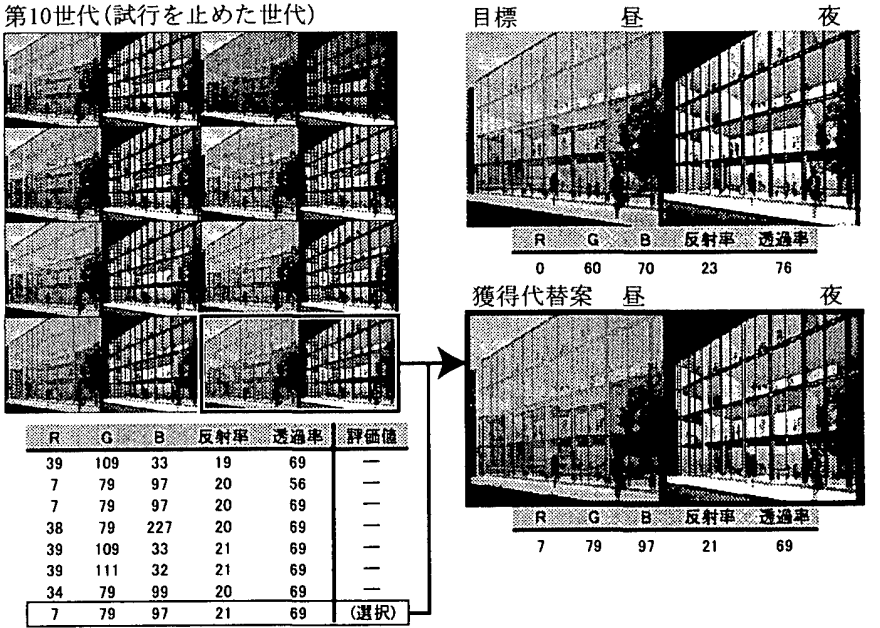


2)「選定者」の目標とする印象をもたらすガラスの探索

1)において、C G画像を目標とした場合にある程度近似した性能 值が得られることが確認された。ここでは、あるプロジェクトの事 例䄇5) を対象に、「選定者」注6)の目標の印象をもたらすガラスの探 索を試みる。図10のようなホテル建築の客室部分のガラスファサー ドに対し、「選定者」は、自ら描いた図11のスケッチで表されるよ うな、一部屋当たりの外観の印象を求めた。ガラスには白色のハー 第0世代(初期世代)

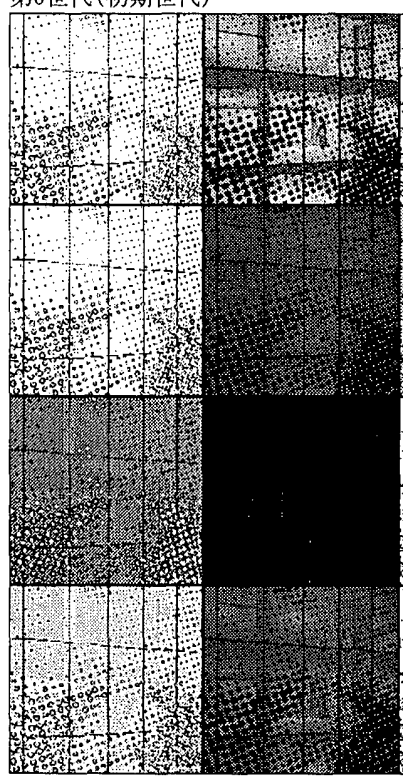

\begin{tabular}{|c|c|c|c|c|c|}
\hline & 6 & B & 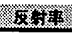 & 28 & 1 I \\
\hline 221 & 188 & 111 & & 69 & \\
\hline 209 & 104 & 30 & 23 & 74 & 5 \\
\hline 223 & 241 & 212 & 45 & 29 & 2 \\
\hline 49 & 89 & 93 & 29 & 29 & \\
\hline 244 & 51 & 238 & 11 & 28 & 3 \\
\hline 180 & 230 & 203 & 66 & 18 & 2 \\
\hline 8 & 232 & 135 & 22 & 45 & \\
\hline 207 & 11 & 28 & 48 & & \\
\hline
\end{tabular}

第14世代
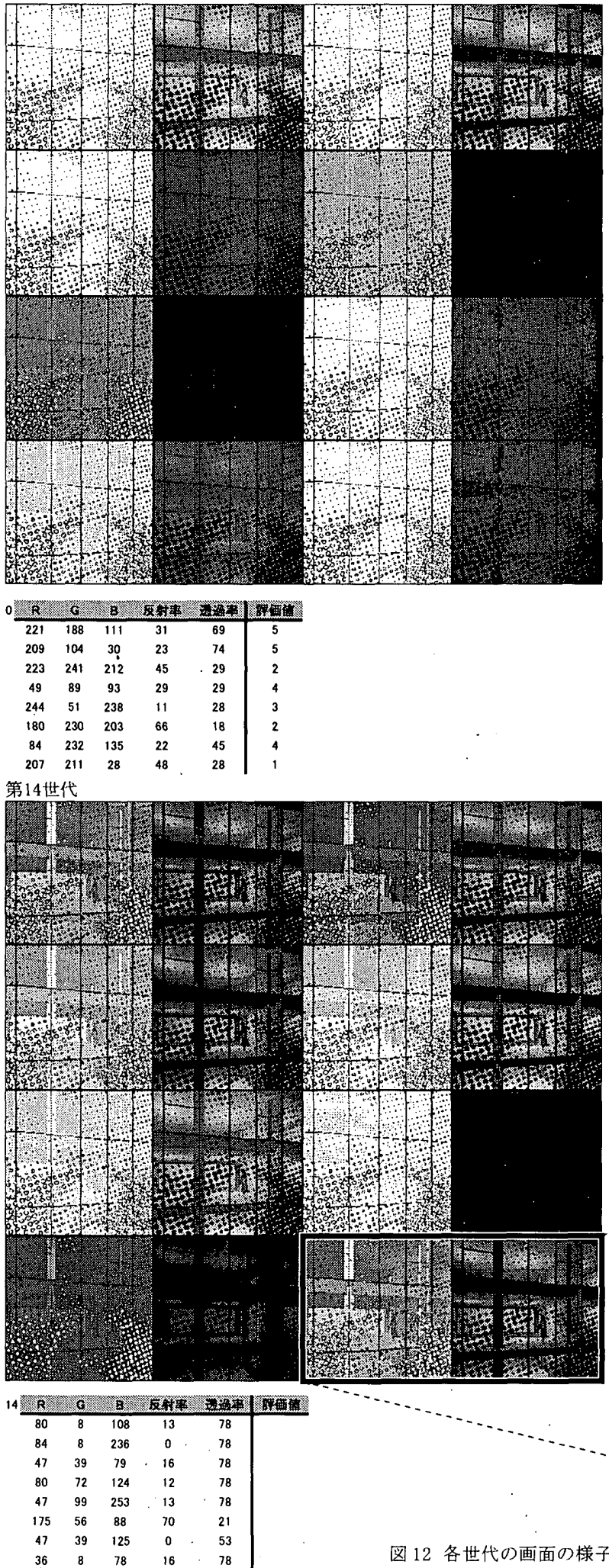

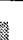

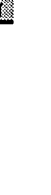

\begin{abstract}
(1)
\end{abstract}

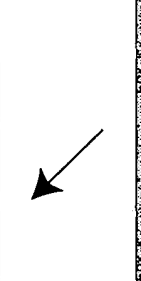

フトーンパターン状のセラミックプリント注7) が施されることが与 件として決定している。ここで昼間と夜間で図と地の関係が反転す るような印象、すなわち昼間は半透明のガラスに白のパターン、夜 間は内部の透けたガラスに黒のパターンとなる外観をもたらすガラ スを探索した。ハーフトーンパターンは白色で、条件は固定とした。
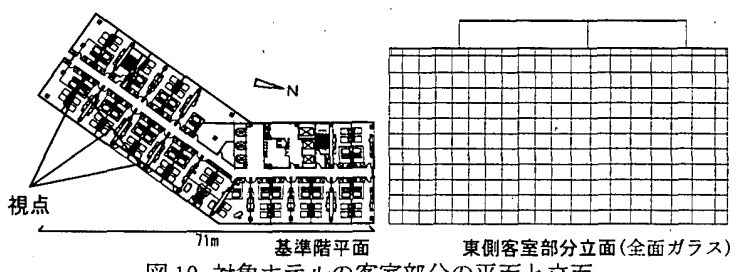

図 10 対象ホテルの客室部分の平面と立面
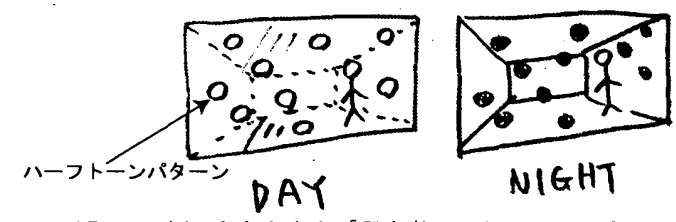

図 11 目標の印象を表寸「選定者」によるスケッチ
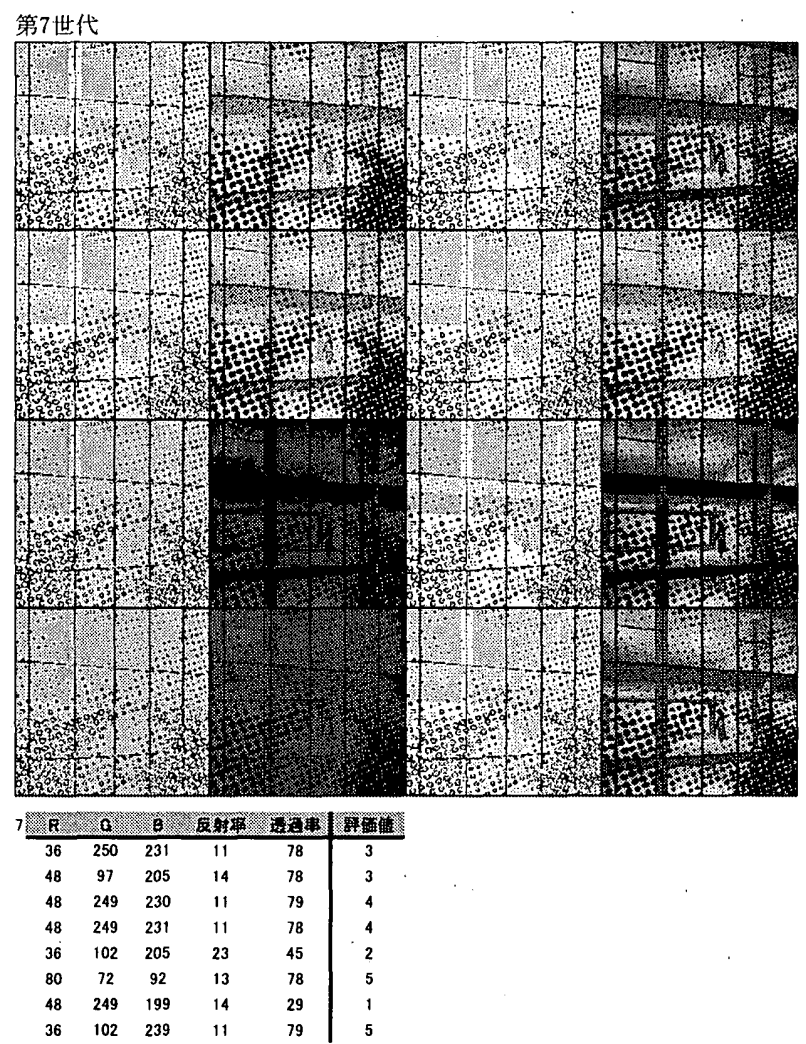

㺘得代替案（屋）

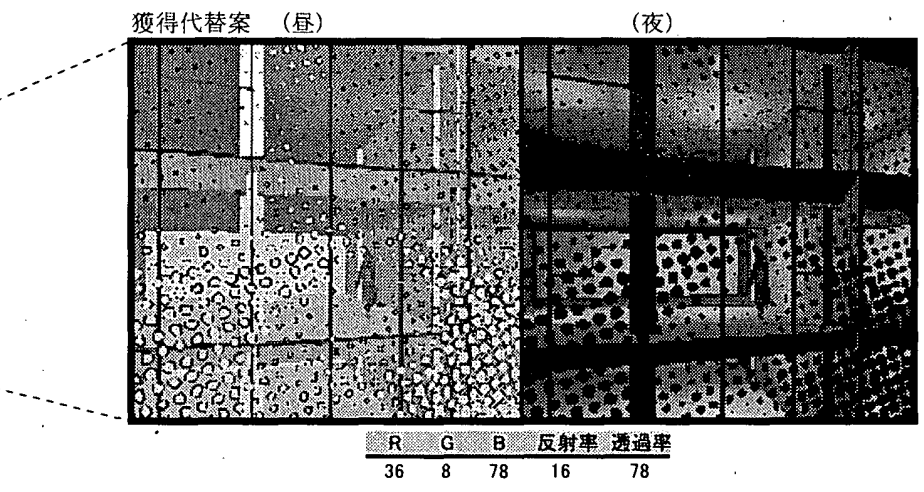

図 12 各世代の画面の様子と第14 世代において選択された代替案 


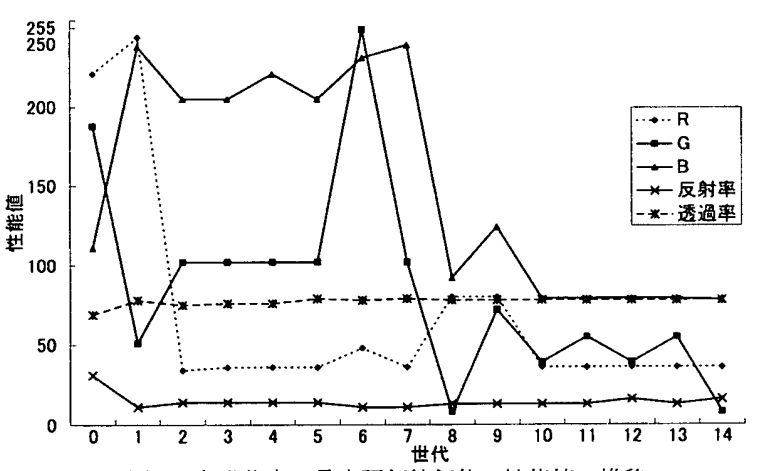

図 13 各世代内の最良評価值個体の性能値の推移

第14世代において、「選定者」は目標の印象に適う代替案を得て、 試行を終了した。各世代の画面の様子と、最終的に選択された代替 案、そのガラスの性能值を図 12 に、各世代の最良評価値個体の性能 值の推移を図 13 に示した。初期世代から第 7 世代辺りまでは、ガラ スの透明感の割に反射が大きく、昼間のハーフトーンパターンが認 識されにくいものが多かった。夜間の画像においても、建物内部が あまり透過して見えないために、パターンが判別しにくくなったり、 逆にガラスのみの部分よりも明るく見えるものがあった。第 8 世代 辺りから以降は、夜間の画像については、かなり目標に近いものが 現れてきた。一方、昼間の画像については、ガラスのみの地の部分 が白っぽく明るいため、パターンが埋没して、あまり目立たないも のしかなかった。また世代毎の代替案全体の傾向として、第 11 世代 辺りまでは、異なった特徴を示す代替案が混合して世代内に存在し ていたが、次第にどの代替案も一定の似通った特徵を持つようにな り、その共通の枠組みの中で、微妙な差異を有する代替案が多数を 占めるようになって行った。このことは、はじめは「選定者」の評 価の高い性能值の組み合わせを比較的広範に探索し、世代を経るに したがって「選定者」の評価を反映した遺伝的オペレータが適当に 用いられることによって、次第に「選定者」の評価の高い遺伝子の 部分構造が形成されて、その構造の枠組みを維持することで、問題 空間を絞り込み、探索を行っている様子を表しているのではないか と予測される。また、これは遺伝的アルゴリズムにおける積み木仮

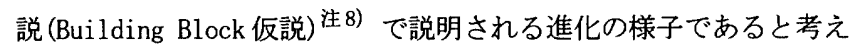
られる。第 11 世代辺りから、昼間においてもパターンが祭立って見 え、かつ部屋内部の奥行きが半透明のガラスの向こうに認識される ような、目標に近似した代替案が現れるようになった。第 14 世代に おいて選択された代替案は、十分「選定者」の求める印象に近似し たものであった。

\section{7. まとめ}

はじめに、本論で提示する方法により、有効に代替案の探索がな されるか検討するために、予め作成され、目標として与えられたC G画像のガラスの性能值の探索を行った。全くランダムに生成され た初期世代から試行を開始して、第10世代において、目標の印象に 十分近似しているとみなせる代替案を得た。目標のガラスの性能值 と、獲得された代替案のガラスの性能值を比較すると、特に大きく 異なる值がなく、概ね近似していることが確かめられた。このこと より、目標の印象が明確に存在する場合に、それに近似した印象を もたらす代替案を短時間の内に効率的に探索できることが提示され た。ガラスの性能值の探索において、CGの高度な現実空間の再現
性と、人間の感性評価の能力と、多点探索を行う進化計算による適 応システムの利点を適切に組み合わせて用いる本論の方法が有効で あることを示した。さらに、ある建物事例を対象に試行を行い、「選 定者」の求める印象のガラスの性能値の同定を行った。「選定者」は ガラスの見え方の微妙な差異を総合的に判断して、画像のガラスの 持つどのような特性が原因であるのか不明であるが、どちらかとい えばこの代替案の方が目標に近いと思われる、という主観的な評価 を行うことで、目標とする印象に近づいて行く過程が見られた。得 られる特性值はC G 精度に依存するが、対象の適切なモデル化に よって、本論の方法が適用可能であることを提示した。複数の指標 からなるガラスの性能值を探索する問題は多目的な問題であるとい える。これに対して本論では、人間の感性の、対象を直感的、総合 的に評価する能力を用いる方法を提示した。多目的性を維持しなが ら、効率的に目標に接近して行く方法は、今後コンピュータの演算 能力と共に C G の再現性が一層向上し、 $\mathrm{C} \mathrm{G}$ 上の特性とガラスの物 理的特性の精緻なデータの作成により両者の摺り合わせが行われる ことで、より正確なガラスの同定に発展して行くことが可能である。 謝辞

本論は、日本建築学会大会で発表された田中、宗本、松下の学術講演梗概文解 11 )、田中の 京都大学修士論文文嚆12) をもとにしている。炚中理恵氏(現在伊東豊雄建筑設計事務所) に は対話型GAシステムの作成において多大な協力を頂いた。感敦いたします。 注积

注1)レイ・トレーシング法 (ray tracing algorithm: 光線追跡法) とは、モデルの表面 形状、色、反射率、透過率および背景の同様の条件を考虑し、光線一本一本を追跡し、 演算するもので、高度な表現効果を得ることができるとされている。

注2）仹イーフロンティア社のShade Professional version6を用いた。れは建筑設 計分野等で広く用いられている3 次元CADアプリケーションの一っである。 注 3)モニターの仕槏は次の通りである。名称：EIZO FlexScanL557-FBK、サイズ: $43 \mathrm{~cm}$ 型、パネル：カラーTFT 液晶パネル、画素ピッチ：0.264mm 角、最大表示色 1677 万色、 表示階調 : 256 階調、輝度 : $250 \mathrm{~cd} / \mathrm{m}^{2}$ 、色温度 : $6500 \mathrm{~K}$

注4)ここでは、ある建箘設計を学ぶ大学院生（1名）が「選定者」となった。 注 5) OMA Asia Ltd. (現 RAD) Sheraton Grande Walkerhill new annex (伊 hotels) 注6)ここでは、ある建筑設計を専門とする者（1名）が「選定者」となった。 注7)ハーフトーンパターン(網点) とは，写真イメージを印刷する際の印刷手法であ り、漠度によって大きさの異なる点を並べることによって、画像を表現するものであ る。すなわちここでは、網点状にセラミックプリントが施されるガラスのシミュレー ションを行う。

注8)GAには、「Gの集団はスキーマ(schema) と呼ばれる最適解の部分解を保持する! というスキーマ定理と、「交叉、突然変黑によってそのスキーマを組み合わせて最適解 を構成して行く」という積み木仮説がある。

\section{参考文献}

1)金鍾河, 平尾和洋, 川崎 清: 視点 - 視対象間距離と色彩変化の関係，CGによる距離感 表現に関する研究その1, 計画系論文集, NO. 475, P. 209, 1995年

2)金 鍾河, 大影佳史, 平尾和洋, 川崎 清: 視点・視対象間距離による建物の色彩変化 ，CGによる建物の距離感表現に関する研究，計画系論文集，NO. 486，P. 241，1996年 3)川猗寧史, 宗本順三, 大影佳史：CGに上る色彩遠近効果の景観描与法に関寸る研究, フィ ル夕処理操作による色彩遠近効果の研究，計画系論文集，N0.511，P. 153，1998年 4) 中山和美, 传藤仁人, 澤田敏実: ニューラルネットワークを用いた建物外観色彩選定法 の研究，計画系論文集，N0.510，P.9，1998年

5) Ken Aoki and Hideyuki Takagi: 3-D CG Lighting with an Interactive CA, vol.1 of the Proceedings of the 1st Int. Conf. on Conventional and Knowledge-based Intelligent Electronic Systems (KES' 97), Adelaide Australia, May. 1997.

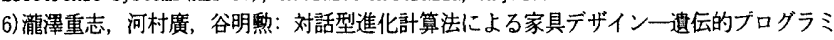
ングによるユーザーの嗜好の定量化と予测，日本建築学会情報システム技術委員会 第23 回情報システム利用シンポジウム， p. 175，2000

7)松下大軲, 宗本順三：対話型進化計算による形態構成規則の獲得モデル，計画系論文集 NNo. $560, P .135,2002$ 年

8)李ワイ強，位寄和久，両角光男：インタラクティブ色彩計画システム，計画系論文集 ，N0. $537 ，$ P. 325, 2000年 11 月

9)宗本晋作，加藤直樹，今村元一：直交グラフ描画法を用いた室配圈手法，タブー探索法 を用いた対話型多目的最適化，計面系論文集，N. No. 529,P. 279, 2000年 3 月

10) Thang C. Nguyen, David E. Goldberg, Thomas S. Huang: Evolvable Modeling: structural adaptaion through hierarchical evolution for 3-D model-based vision, Beckman Institute and Coordinated Science Laboratory, University of Illinois, 1993

11)田中理惠、宗本順三、松下大輔：対話型G Aを用いたフアサードガラスの選定システム 日本建築学会大会学術講演梗概集, E1 (建築計画 I), p. 493, 2002年8月

12)田中理恵: 感性評価の学習を用いた対話型進化計算によるファサードガラス同定法の研 究，京都大学修士論文，2003年 2 月

（2003年12月15日原稿受理，2004年 6 月 9 日採用決定） 